\title{
Intermetallic Compounds Formed during Interfacial Reactions between Liquid Sn-8Zn-3Bi Solders and Ni Substrates
}

\author{
M.Y. CHIU, S.S. WANG, and T.H. CHUANG \\ Department of Materials Science and Engineering, National Taiwan University, Taipei 106, Taiwan
}

The morphology and growth kinetics of intermetallic compounds (IMCs) formed at the interfaces between liquid $\mathrm{Sn}-8 \mathrm{Zn}-3 \mathrm{Bi}$ solders and nickel substrates in the temperature range from $225^{\circ} \mathrm{C}$ to $400^{\circ} \mathrm{C}$ are investigated for the applications in bonding recycled sputtering targets to their backing plates. The results show that a continuous single layer of $\mathrm{Ni}_{5} \mathrm{Zn}_{21}$ IMC appears at temperatures below $325^{\circ} \mathrm{C}$, while a double layer containing $\mathrm{Ni}_{5} \mathrm{Zn}_{21}$ and $\mathrm{Ni}_{35} \mathrm{Zn}_{22} \mathrm{Sn}_{43}$ IMCs is formed at temperatures above $325^{\circ} \mathrm{C}$. In both cases, the growth kinetics of IMCs is interface-controlled. During the growth of IMCs, their reaction fronts migrate in the direction of the solder much more rapidly than toward the nickel substrate, and erosion of the $\mathrm{Ni}$ substrate is quite slight.

Key words: Sn-8Zn-3Bi solder, nickel substrate, intermetallic compound, linear growth kinetics

\section{INTRODUCTION}

For the bonding of recycled sputtering targets to their backing plates, soldering has been commonly employed as a low-temperature joining method. Owing to environmental concerns for $\mathrm{Sn}-\mathrm{Pb}$ solders and the avoidance of costly In-based solders, Sn-Zn alloys have been considered as one alternative because they also possess the advantages of high strength, good creep resistance, and high thermal fatigue resistance. ${ }^{1}$ By adding $\mathrm{Bi}$ into $\mathrm{Sn}-\mathrm{Zn}$ solders, the melting point can be decreased, and the greater the amount of $\mathrm{Bi}$ rendered, the lower the melting point. ${ }^{2}$ Bismuth also helps improve the wettability and corrosion performance of Sn-Zn solders. ${ }^{3}$ However, the formation of the Bi-rich phase in Bi-contained solders might weaken the mechanical properties of the soldered joints. ${ }^{3}$

Although copper is widely used as the backingplate material for sputtering targets, its high erosion into Sn-based solders has constituted an annoying problem. To eliminate this problem, a nickel backing plate or copper deposited with nickel as a diffusion barrier is considered. The interfacial reactions between $\mathrm{Sn}-\mathrm{Zn}-\mathrm{Bi}$ solders and Ni substrates during the soldering process are thus worth investigating. For the thermal aging (solid/solid) reactions and soldering (liquid/liquid) reactions between pure $\mathrm{Bi}$ and $\mathrm{Ni}$ substrates, a number of researchers have reported

(Received August 10, 2001; accepted January 16, 2002) only on $\mathrm{NiBi}_{3}$ intermetallic compounds (IMCs) that form at the $\mathrm{Bi} / \mathrm{Ni}$ interface. ${ }^{4-9}$ The $\mathrm{NiBi}_{3}$ intermetallic compounds appear not only at the $\mathrm{Bi} / \mathrm{Ni}$ interface but also in the Bi solder matrix due to the dissolution of $\mathrm{Ni}$ into liquid $\mathrm{Bi}^{7,9}$ According to their investigations, the $\mathrm{NiBi}_{3}$ formed as a layer at the interface, which the compound in the Bi solder matrix forms as large needles. During thermal aging of a $\mathrm{Bi} / \mathrm{Ni}$ diffusion couple, the growth kinetics of $\mathrm{NiBi}_{3}$ at the interface is diffusion-controlled. ${ }^{4,5}$ In the case of $\mathrm{Sn}$ $58 \mathrm{Bi} / \mathrm{Ni}$ interfacial reactions, a $\mathrm{Ni}_{3} \mathrm{Sn}_{4} \mathrm{IMC}$ has been observed. ${ }^{9-11}$ Kinetics analyses have been conducted for thermally aged specimens, and the growth of such $\mathrm{Ni}_{3} \mathrm{Sn}_{4}$ IMCs has been shown to be diffusioncontrolled with an activation energy of $90 \mathrm{~kJ} / \mathrm{mol} .^{10}$ The interfacial reactions of $\mathrm{Sn}-8.5 \mathrm{Zn}-5.5 \mathrm{Bi}$ solders with nickel, copper, brass, and nickel-iron substrates after thermal aging at a temperature of $125^{\circ} \mathrm{C}$ for 100 days have also been studied, and the appearance of $\mathrm{Ni}_{5} \mathrm{Zn}_{21}$ IMCs was reported. ${ }^{3}$ When Sn-8.5Zn$5.5 \mathrm{Bi}$ solders react with $\mathrm{Ni}$ and other substrates, the growth kinetics of interfacial IMCs has not been investigated. Therefore, this study identifies the IMCs formed during the soldering reactions between liquid Sn-8Zn-3Bi solders and Ni substrates at temperatures ranging from $225^{\circ} \mathrm{C}$ to $400^{\circ} \mathrm{C}$. In addition, the growth kinetics of these IMCs is evaluated.

\section{EXPERIMENTAL}

The Sn-8Zn-3Bi (wt.\%) solder was prepared by encapsulating pure $\mathrm{Sn}(99.9 \%), \mathrm{Zn}(99.9 \%)$, and $\mathrm{Bi}$ 
(99.99\%) in a quartz tube at a vacuum level of $10^{-5}$ torr and melting at $600^{\circ} \mathrm{C}$. The melting point of this solder was analyzed by a differential scanning calorimeter (DSC). The heating rate of the DSC is $10^{\circ} \mathrm{C} /$ min under $\mathrm{N}_{2}$ atmosphere.

For the solder reactions, the Sn-8Zn-3Bi solder ingot was cold-rolled into 0.2 -mm-thick foil. Then, the solder foils were sliced into specimens $(10 \mathrm{~mm} \times$ $8 \mathrm{~mm} \times 0.1 \mathrm{~mm})$. A 1 -mm-thick Ni plate $(99.9 \% \mathrm{Ni})$ was cut into the same size as the solder foils. The $\mathrm{Ni}$ substrates were ground with $\mathrm{SiC}$ paper, polished with 1 and $0.3 \mu \mathrm{m} \mathrm{Al}_{2} \mathrm{O}_{3}$ powder, cleaned with acetone and alcohol, and dipped with rosin mildly activated (RMA) type flux. The Sn-8Zn-3Bi solder foil was placed on the Ni substrate and the sample was heated in an infrared furnace under a vacuum of $10^{-3}$ torr. Soldering was performed in the temperature range between $225^{\circ} \mathrm{C}$ and $400^{\circ} \mathrm{C}$; for 10 to 150 min, then, the sample was rapidly cooled to the room temperature in $2 \mathrm{~min}$.

The soldered specimens were cut along the cross section, ground with $\mathrm{SiC}$ paper, polished with 1 and $0.3 \mu \mathrm{m} \mathrm{Al}{ }_{2} \mathrm{O}_{3}$ powders, and ultrasonically cleaned with acetone and alcohol. The microstructure of the interface was investigated with a scanning electron microscope (SEM). The composition of the IMCs was identified by an electron-probe microanalyzer (EPMA) and x-ray diffractometer (XRD). The samples for XRD analyses were prepared by selectively etching out the unreacted solder with a solution consisting of $1 \mathrm{~mL} \mathrm{HF}, 15 \mathrm{~mL} \mathrm{H}_{2} \mathrm{SO}_{4}$, and $84 \mathrm{~mL}$ $\mathrm{H}_{2} \mathrm{O}$. In order to clarify the formation mechanism of the IMC, the surface of $\mathrm{Ni}$ substrate was partially sputter-coated with a Ta thin film. Because the Ta thin film does not react with the solder or the substrate, it could well serve as a reaction marker to identify the original interface between $\mathrm{Ni}_{(\mathrm{s})}$ and solder $(\mathrm{l})$.

\section{RESULTS AND DISCUSSION}

The DSC analyses of the Sn-8Zn-3Bi solder reveal a sharp endothermic peak at $197.7^{\circ} \mathrm{C}$, which is near the melting point $\left(198.5^{\circ} \mathrm{C}\right)$ of the eutectic binary Sn-9Zn alloy. Figure 1 illustrates the microstructure

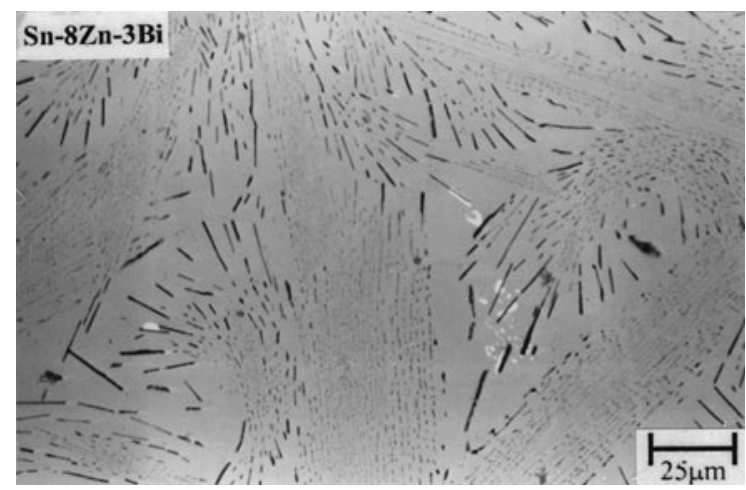

Fig. 1. Morphology of the as-cast Sn-8Zn-3Bi solder.

of the as-cast $\mathrm{Sn}-8 \mathrm{Zn}-3 \mathrm{Bi}$ solder, which possesses a great deal of platelike Zn-rich precipitates (shown in black), as well as a small amount of Bi-rich precipitates (white) embedded in the $\beta$-Sn matrix (gray). The morphology of IMCs formed at the Sn-8Zn$3 \mathrm{Bi} / \mathrm{Ni}$ interfaces after soldering reaction at various temperatures for $120 \mathrm{~min}$ is shown in Fig. 2. There is only one type of IMC that appears at the interface at lower temperatures (below $325^{\circ} \mathrm{C}$ ). The EPMA results from Table I give the composition profile of such an IMC: 17.07 to $18.29 \mathrm{Ni}, 79.22$ to $80.75 \mathrm{Zn}$, 0.17 to $2.24 \mathrm{Sn}$, and 0 to $0.05 \mathrm{Bi}$ (at.\%). The composition corresponds to a stoichiometric $\mathrm{Ni}_{5} \mathrm{Zn}_{21}$ type of IMC, which can be confirmed by the XRD analyses of the reacted specimen after selectively etching the solder. For most Sn-based solders such as $\mathrm{Sn}-\mathrm{Pb}, \mathrm{Sn}-$ $\mathrm{Bi}, \mathrm{Sn}-\mathrm{Ag}$, and $\mathrm{Sn}-\mathrm{Cu}$, their interfacial reactions with $\mathrm{Ni}$ substrates result in the formation of $\mathrm{Ni}_{3} \mathrm{Sn}_{4}$ IMC. The appearance of a different IMC $\left(\mathrm{Ni}_{5} \mathrm{Zn}_{21}\right)$ at the $\mathrm{Sn}-8 \mathrm{Zn}-3 \mathrm{Bi} / \mathrm{Ni}$ interface is attributed to the active nature of the element $\mathrm{Zn}$. In Fig. 2, when the soldering temperatures increase to above $325^{\circ} \mathrm{C}$, a double layer of IMCs can be observed. Table I shows that the outer layer (IMC1) possesses a composition similar to that of the IMC formed at temperatures below $325^{\circ} \mathrm{C}$ when the $\mathrm{Sn}$ and $\mathrm{Bi}$ contents are slightly higher. In contrast, the composition of the inner intermetallic layer (IMC2) is 29.93 to 34.78 $\mathrm{Ni}, 21.12$ to $22.70 \mathrm{Zn}, 43.00$ to $48.70 \mathrm{Sn}$, and 0.09 to

Table I. Chemical Compositions (At.\%) of the IMCs Formed at the Sn-8Zn-3Bi/Ni Interface after Soldering Reactions at Various Temperatures for $120 \mathrm{Min}$

\begin{tabular}{|c|c|c|c|c|c|}
\hline Temperature & IMCs & $\mathbf{N i}$ & $\mathbf{Z n}$ & Sn & $\mathbf{B i}$ \\
\hline $225^{\circ} \mathrm{C}$ & $\mathrm{Ni}_{5} \mathrm{Zn}_{21}$ (Single layer $)$ & 17.56 & 80.50 & 0.20 & 0 \\
\hline $250^{\circ} \mathrm{C}$ & $\mathrm{Ni}_{5} \mathrm{Zn}_{21}$ (Single layer) & 17.25 & 79.22 & 0.17 & 0.02 \\
\hline $275^{\circ} \mathrm{C}$ & $\mathrm{Ni}_{5} \mathrm{Zn}_{21}$ (Single layer) & 17.89 & 79.67 & 0.24 & 0.05 \\
\hline $300^{\circ} \mathrm{C}$ & $\mathrm{Ni}_{5} \mathrm{Zn}_{21}$ (Single layer) & 17.07 & 80.75 & 2.17 & 0 \\
\hline $325^{\circ} \mathrm{C}$ & $\mathrm{Ni}_{5} \mathrm{Zn}_{21}$ (Single layer) & 18.29 & 79.40 & 2.20 & 0.04 \\
\hline \multirow[t]{2}{*}{$350^{\circ} \mathrm{C}$} & $\mathrm{Ni}_{5} \mathrm{Zn}_{21}$ (Outer layer) & 16.51 & 79.83 & 3.60 & 0.08 \\
\hline & $\mathrm{Ni}_{35} \mathrm{Zn}_{22} \mathrm{Sn}_{43}$ (Inner layer) & 34.78 & 22.13 & 430 & 0.09 \\
\hline \multirow[t]{2}{*}{$375^{\circ} \mathrm{C}$} & $\mathrm{Ni}_{5} \mathrm{Zn}_{21}$ (Outer layer) & 16.34 & 80.16 & 3.42 & 0.08 \\
\hline & $\mathrm{Ni}_{35} \mathrm{Zn}_{22} \mathrm{Sn}_{43}$ (Inner layer) & 33.19 & 22.70 & 44.01 & 0.10 \\
\hline \multirow[t]{2}{*}{$400^{\circ} \mathrm{C}$} & $\mathrm{Ni}_{5} \mathrm{Zn}_{21}$ (Outer layer) & 16.95 & 78.14 & 4.89 & 0.02 \\
\hline & $\mathrm{Ni}_{35} \mathrm{Zn}_{22} \mathrm{Sn}_{43}$ (Inner layer) & 29.93 & 21.12 & 48.70 & 0.25 \\
\hline
\end{tabular}




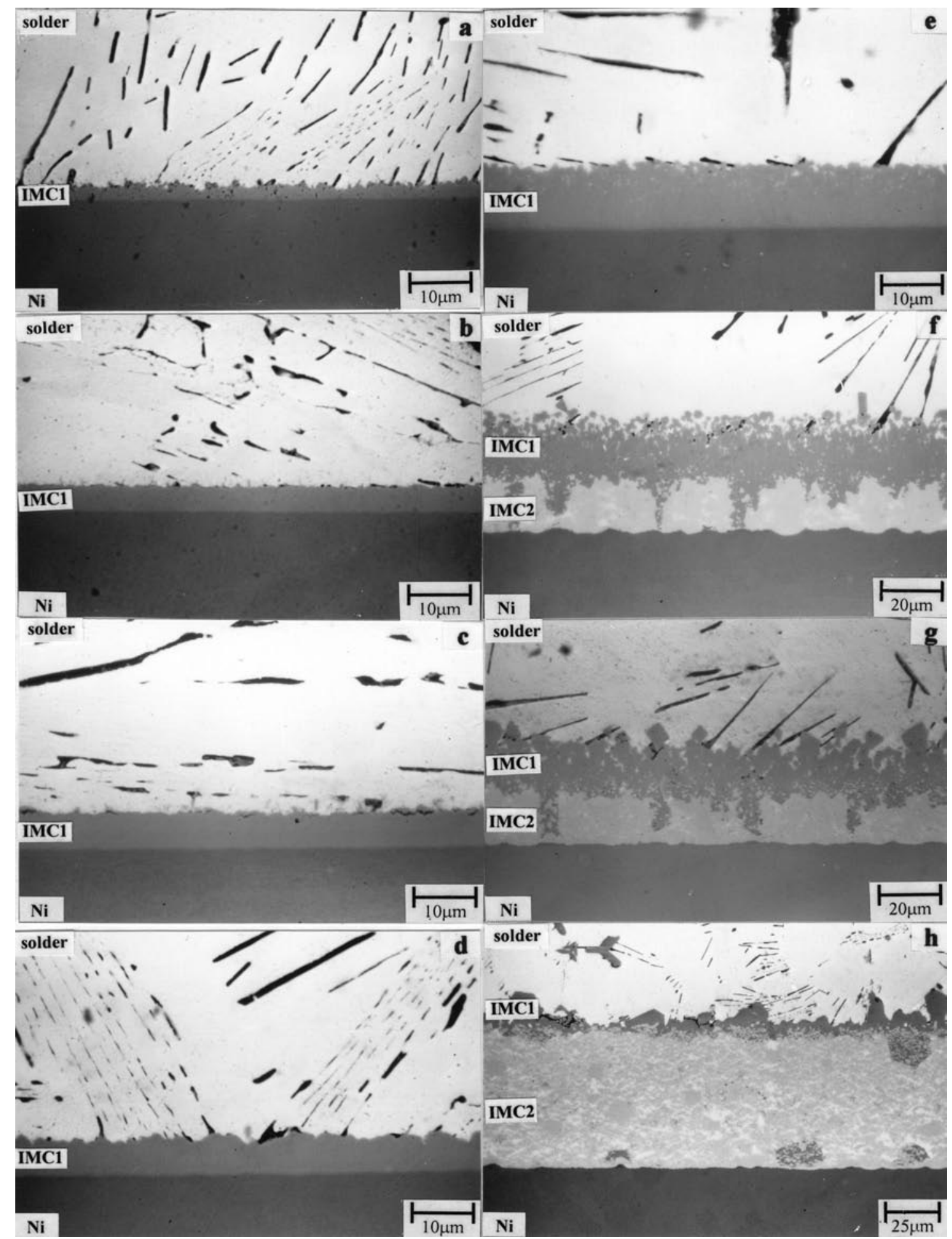

Fig. 2. The SEM micrographs of the intermetallic compounds formed at $\mathrm{Sn}-8 \mathrm{Zn}-3 \mathrm{Bi} / \mathrm{Ni}$ interface after soldering reactions at various temperatures for $120 \mathrm{~min}$ : (a) $225^{\circ} \mathrm{C}$, (b) $250^{\circ} \mathrm{C}$, (c) $275^{\circ} \mathrm{C}$, (d) $300^{\circ} \mathrm{C}$, (e) $325^{\circ} \mathrm{C}$, (f) $350^{\circ} \mathrm{C}$, (g) $375^{\circ} \mathrm{C}$, and (h) $400^{\circ} \mathrm{C}$. 


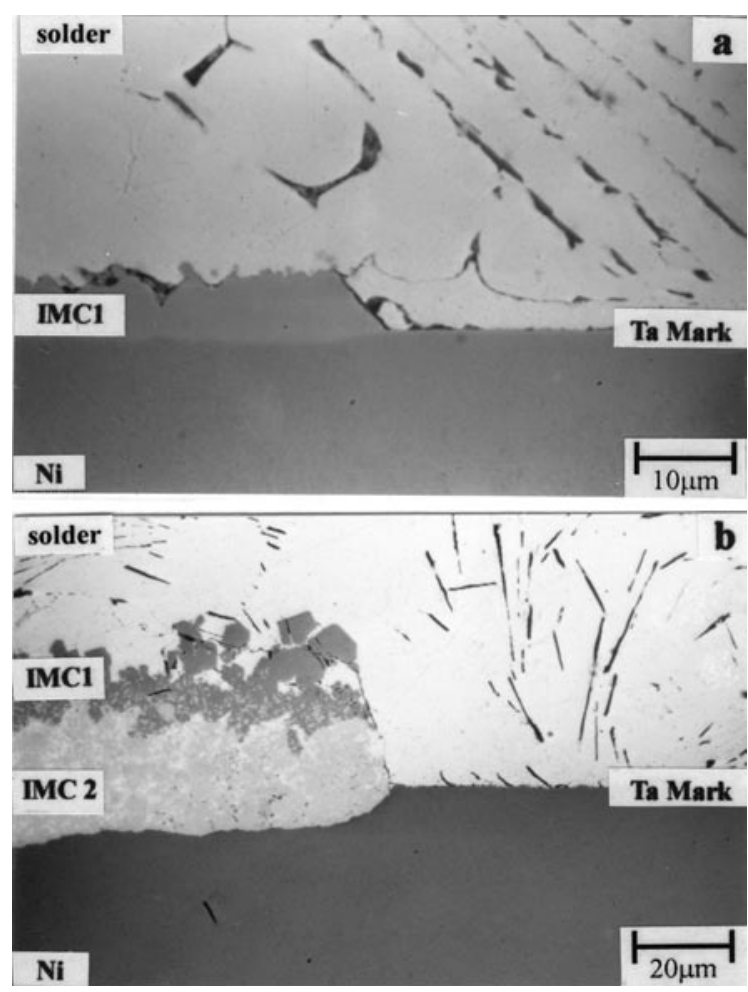

Fig. 3. Growth of intermetallic compounds (IMCs) at Sn-8Zn-3Bi/Ni interface after soldering reaction at (a) $300^{\circ} \mathrm{C}$ and (b) $375^{\circ} \mathrm{C}$ for 120 min. (The original interface was marked with a Ta thin film.)

$0.25 \mathrm{Bi}$ (at.\%). Such a composition corresponds to a stoichiometric $\mathrm{Ni}_{35} \mathrm{Zn}_{22} \mathrm{Sn}_{43}$ type of IMC.

Though partial sputtering of the Ta thin film on the surface of the $\mathrm{Ni}$ substrate sets up a reaction barrier between $\mathrm{Sn}-8 \mathrm{Zn}-3 \mathrm{Bi}$ and $\mathrm{Ni}$, the original $\mathrm{Sn}-$ $8 \mathrm{Zn}-3 \mathrm{Bi} / \mathrm{Ni}$ interface can be marked. From Fig. 3, a slightly sunken curvature is formed at the Sn-8Zn$3 \mathrm{Bi} / \mathrm{Ni}$ interface in the area adjacent to the Ta marker, which only implies that a small amount of $\mathrm{Ni}$ dissolved from the $\mathrm{Ni}$ substrate into the liquid Sn-8Zn-3Bi solder. For the soldering reactions at higher temperatures (e.g., $\left.375^{\circ} \mathrm{C}\right)$, the Ta marking pinpoints the original $\mathrm{Sn}-8 \mathrm{Zn}-3 \mathrm{Bi}$ solder interface to be situated between the IMC1/IMC2 interface and the IMC2/Ni reaction front. In all cases, the reaction fronts of the IMCs migrate much more rapidly in the direction of the Sn-8Zn-3Bi solder.

The $\mathrm{Ni}_{5} \mathrm{Zn}_{21}$ type IMC formed at temperatures below $325^{\circ} \mathrm{C}$ grows with an increase of reaction time, as shown in Fig. 4. The thickness ( $\mathrm{x}$ ) of such intermetallic layers formed at temperatures below $325^{\circ} \mathrm{C}$ is measured and plotted on a $\log \mathrm{x}$ vs. $\log \mathrm{t}$ scale, as shown in Fig. 5. The slopes of these plots give the $n$ values of the kinetic relation $\mathrm{x}=\mathrm{t}^{\mathrm{n}}$. The $\mathrm{n}$ values range from 0.92 to 1.24 , which implies that the growth of such $\mathrm{Ni}_{5} \mathrm{Zn}_{21}$ intermetallic layers is interface-controlled.

For the soldering reactions between $\mathrm{Sn}-8 \mathrm{Zn}-3 \mathrm{Bi}$ and $\mathrm{Ni}$ substrate above $325^{\circ} \mathrm{C}$, SEM micrographs in Figs. 6 and 7 show that the $\mathrm{Ni}_{35} \mathrm{Zn}_{22} \mathrm{Sn}_{43}$ intermetallic layer (IMC2) forms after the $\mathrm{Ni}_{5} \mathrm{Zn}_{21}$ in-

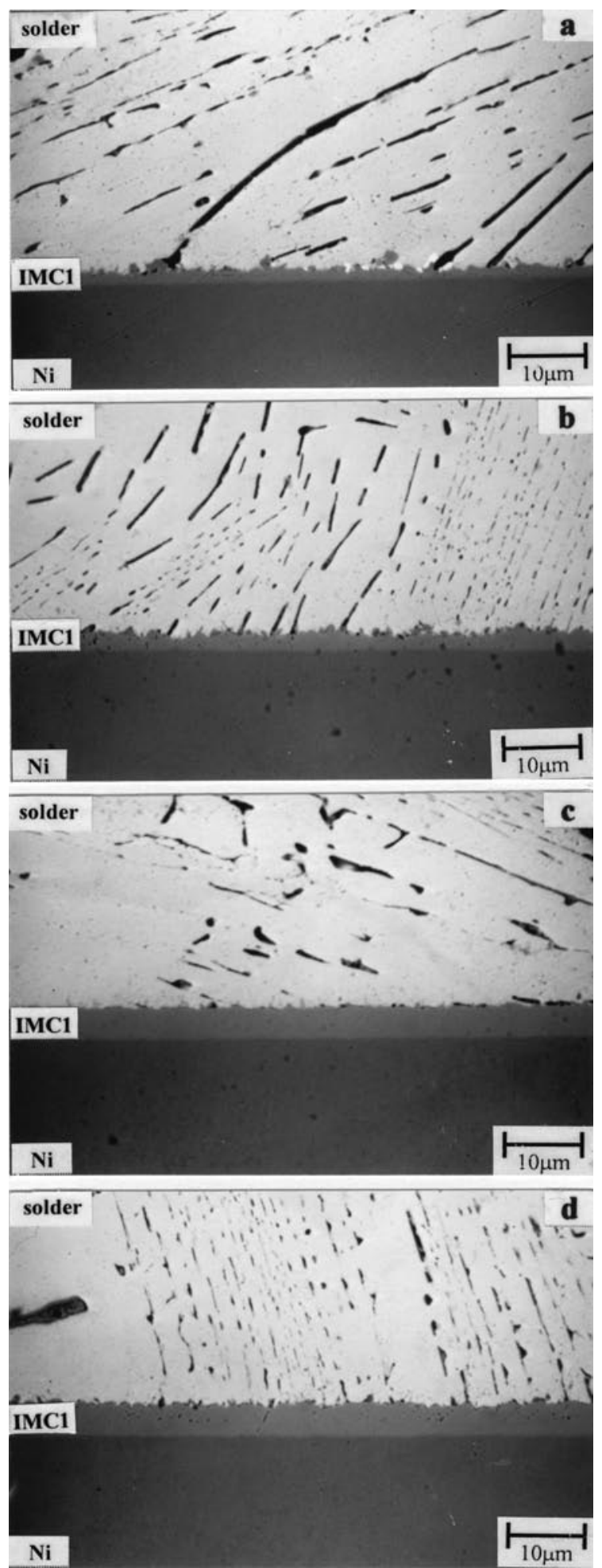

Fig. 4. Growth of single layer of intermetallic compound during the soldering reactions between $\mathrm{Sn}-8 \mathrm{Zn}-3 \mathrm{Bi}$ and $\mathrm{Ni}$ substrate at $250^{\circ} \mathrm{C}$ for various times: (a) $60 \mathrm{~min}$, (b) $90 \mathrm{~min}$, (c) $120 \mathrm{~min}$, and (d) $150 \mathrm{~min}$.

termetallic layer (IMC1) to grow with the increase of reaction time. It is obvious that at $400^{\circ} \mathrm{C}$ the growth of $\mathrm{Ni}_{35} \mathrm{Zn}_{22} \mathrm{Sn}_{43}$ (IMC2) becomes predominate. The total thickness $(\mathrm{x})$ of the double layer (IMC1 + IMC2) formed at temperatures above $325^{\circ} \mathrm{C}$ is also plotted on the same $\log \mathrm{x}$ vs. $\log \mathrm{t}$ 


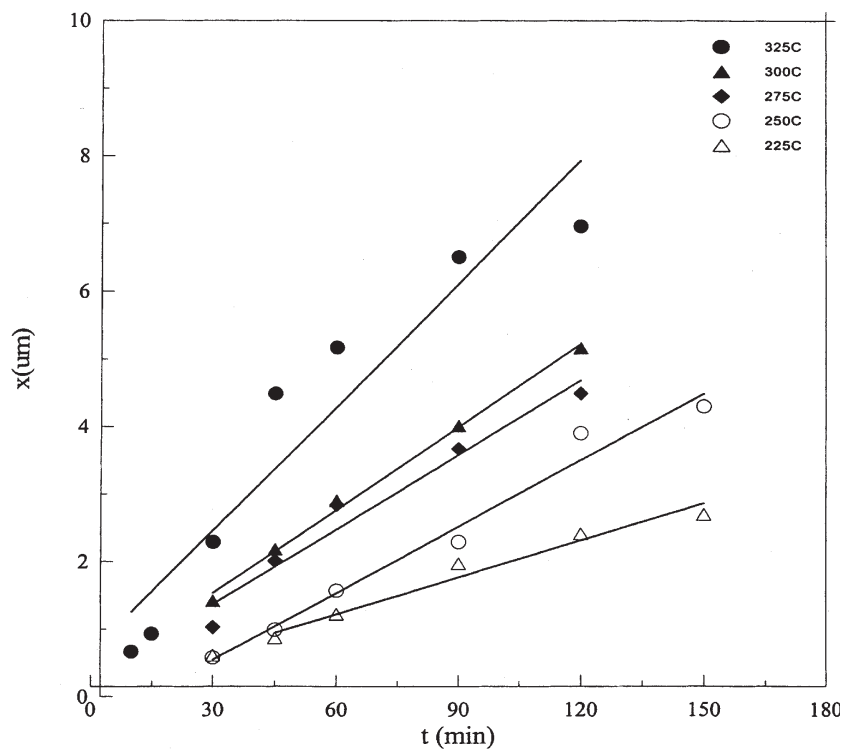

Fig. 5. The thickness $(x)$ of $\mathrm{Ni}_{5} \mathrm{Zn}_{21}$ intermetallic layers formed after soldering reactions between $\mathrm{Sn}-8 \mathrm{Zn}-3 \mathrm{Bi}$ and $\mathrm{Ni}$ substrate at various temperatures below $325^{\circ} \mathrm{C}$ as a function of time (t).

scale, as shown in Fig. 8. The $\mathrm{n}$ values ranging from 0.72 to 1.10 suggest a linear relationship. The results indicate that the growth of doublelayer IMCs during the soldering reactions between $\mathrm{Sn}-8 \mathrm{Zn}-3 \mathrm{Bi}$ and $\mathrm{Ni}$ above $325^{\circ} \mathrm{C}$ is also interfacecontrolled.

For most soldering reactions, the growth kinetics of IMCs formed at the interfaces between liquid solders and solid substrates has been shown to be diffusion-controlled. ${ }^{5,12-15}$ An interface-controlled reaction was reported by $\mathrm{Tu}$ and Thompson for the growth of $\mathrm{Cu}_{6} \mathrm{Sn}_{5}$ IMCs at the interface between thin $\mathrm{Cu}$ and $\mathrm{Sn}$ films. ${ }^{16}$ In that case, the release of $\mathrm{Cu}$ atoms from the $\mathrm{Cu}$ film into $\mathrm{Sn}$ was considered as the rate-limiting step in such a linear growth. In this present study, the linear growth of IMCs during the soldering reactions between liquid $\mathrm{Sn}-8 \mathrm{Zn}-3 \mathrm{Bi}$ and $\mathrm{Ni}$ substrates could be attributed to the rapid diffusion of $\mathrm{Zn}$ atoms in the solder matrix and IMCs, which constitutes the rate-limiting step for the reaction between $\mathrm{Zn}$ and $\mathrm{Ni}$ at the interface.

\section{CONCLUSIONS}

During the soldering reactions between liquid Sn$8 \mathrm{Zn}-3 \mathrm{Bi}$ and $\mathrm{Ni}$ substrates at temperatures ranging from $225^{\circ} \mathrm{C}$ to $325^{\circ} \mathrm{C}$, a continuous single layer of $\mathrm{Ni}_{5} \mathrm{Zn}_{21}$ IMC appears at the $\mathrm{Sn}-8 \mathrm{Zn}-3 \mathrm{Bi} / \mathrm{Ni}$ interface. However, in a higher temperature range from $325^{\circ} \mathrm{C}$ to $400^{\circ} \mathrm{C}$, a double layer containing $\mathrm{Ni}_{5} \mathrm{Zn}_{21}$ and $\mathrm{Ni}_{35} \mathrm{Zn}_{22} \mathrm{Sn}_{43}$ IMCs can be observed. In all cases, plots of the thickness of IMCs as a function of reaction time show a linear reaction, which indicates that the growth kinetics of these IMCs is interfacecontrolled. Through the marking of the original Sn$8 \mathrm{Zn}-3 \mathrm{Bi} / \mathrm{Ni}$ interface using a Ta thin film, it is evident that the Ni substrate dissolves only slightly into the liquid Sn-8Zn-3Bi solder, and the reaction

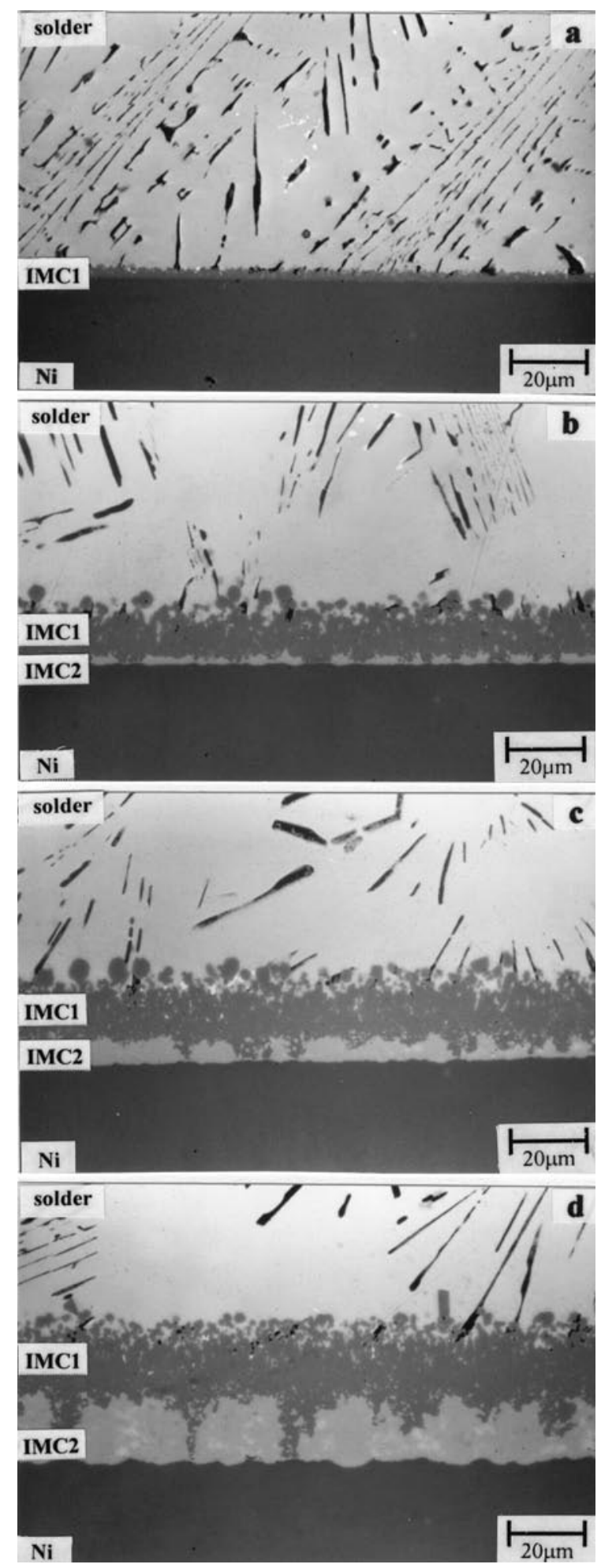

Fig. 6. Growth of double layer of intermetallic compounds (IMC1: $\mathrm{Ni}_{5} \mathrm{Zn}_{21}$, and IMC2: $\mathrm{Ni}_{35} \mathrm{Zn}_{22} \mathrm{Sn}_{43}$ ) during the soldering reactions between $\mathrm{Sn}-8 \mathrm{Zn}-3 \mathrm{Bi}$ and $\mathrm{Ni}$ substrate at $350^{\circ} \mathrm{C}$ for various times: (a) 15 min, (b) $30 \mathrm{~min}$, (c) $60 \mathrm{~min}$, and (d) $120 \mathrm{~min}$.

front of the IMC on the side of the Sn-8Zn-3Bi solder migrates much more rapidly than its counterpart on the other side. 


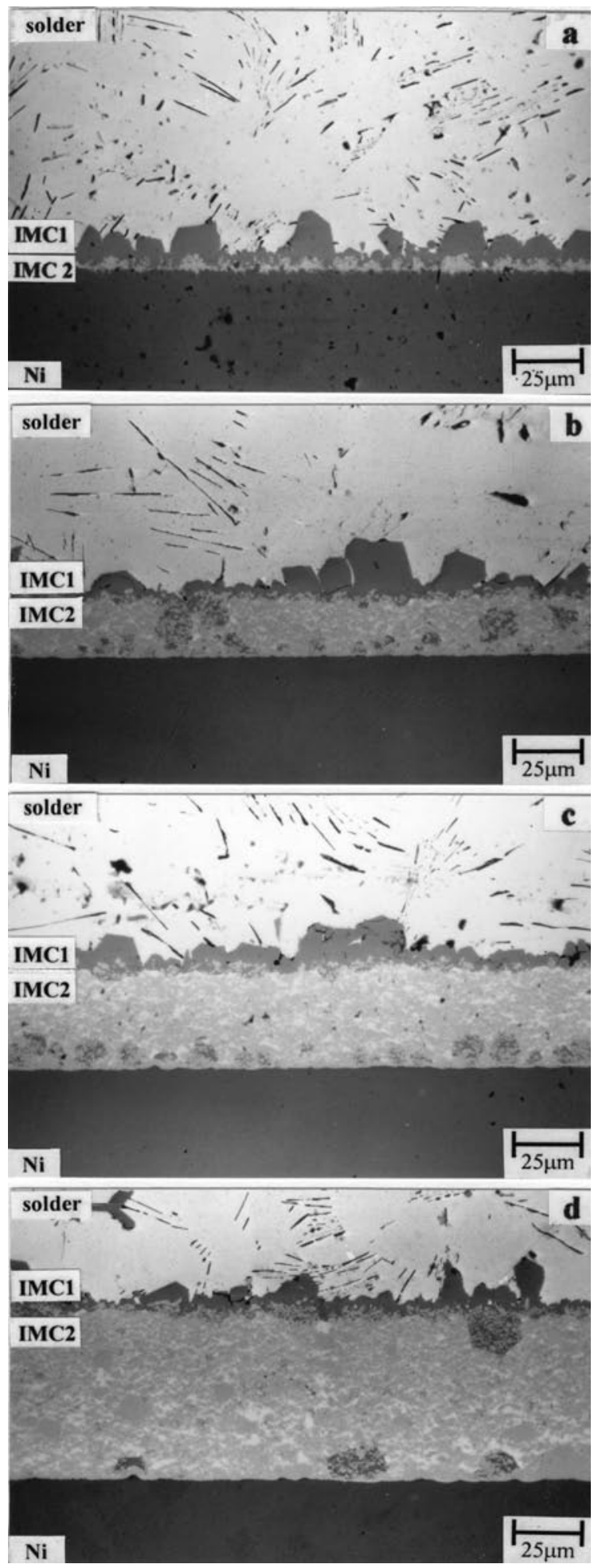

Fig. 7. Growth of double layer of intermetallic compounds (IMC1: $\mathrm{Ni}_{5} \mathrm{Zn}_{21}$, and IMC2: $\mathrm{Ni}_{35} \mathrm{Zn}_{22} \mathrm{Sn}_{43}$ ) during the soldering reactions between $\mathrm{Sn}-8 \mathrm{Zn}-3 \mathrm{Bi}$ and Ni substrate at $400^{\circ} \mathrm{C}$ for various times: (a) 15 min, (b) $30 \mathrm{~min}$, (c) $60 \mathrm{~min}$, and (d) $120 \mathrm{~min}$.

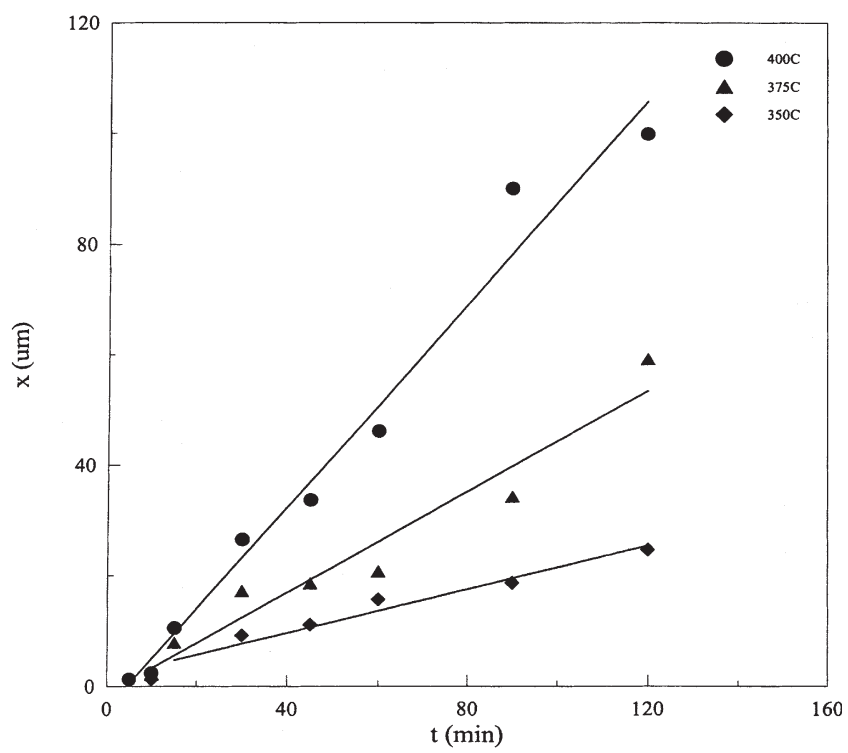

Fig. 8. The total thickness $(x)$ of double layer $\left(\mathrm{Ni}_{5} \mathrm{Zn}_{21}+\right.$ $\mathrm{Ni}_{35} \mathrm{Zn}_{22} \mathrm{Sn}_{43}$ ) intermetallic layers formed after soldering reactions between $\mathrm{Sn}-8 \mathrm{Zn}-3 \mathrm{Bi}$ and $\mathrm{Ni}$ substrate at various temperatures above $325^{\circ} \mathrm{C}$ as a function of time (t).

\section{REFERENCES}

1. N.C. Lee, Adv. Microelectron. 26, 29 (1999).

2. Yoshikazu Nakamura, Yoshinori Sakakibara, Yoshihisa Watanabe, and Yoshiki Amamoto, Soldering Surface Mount Technol. 10/1, 10 (1998).

3. Paul Harris, Soldering Surface Mount Technol. 11/3, 46 (1999).

4. O.V. Duchenko and V.I. Dybkov, J. Mater. Sci. Lett. 14, 1725 (1995).

5. V.I. Dybkov and O.V. Duchenko, J. Alloy Compounds 234, 295 (1996).

6. C.R. Kao, J. Mater. Sci. Eng. A 238, 196 (1997).

7. M.S. Lee, C. Chen, and C.R. Kao, Chem. Mater. 11, 292 (1999).

8. M.S. Lee, C.M. Liu, and C.R. Kao, J. Electron. Mater. 28, 57 (1999).

9. S.K. Kang, R.S. Rai, and S. Purushothaman, J. Electron. Mater. 25, 1113 (1996)

10. C. Chen, C.E. Ho, A.H. Lin, G.L. Luo, and C.R. Kao, J. Electron. Mater. 29, 1200 (2000).

11. B.L. Young and J.G. Duh, J. Electron. Mater. 30, 878 (2001).

12. D.R. Flanders, E.G. Jacobes, and R.F. Pinizzotto, J. Electron. Mater. 26, 883 (1997).

13. L.H. Su, Y.W. Yen, C.C. Lin, and S.W. Chen, Metall. Mater. Trans. B 28B, 927 (1997).

14. S.K. Kang and V. Ramachandran, Scripta Metall. 14, 421 (1980).

15. S. Choi, Y.R. Bieler, J.P. Lucas, and K.N. Subramanian, J. Electron. Mater. 28, 1209 (1999).

16. K.N. Tu and R.D. Thompson, Acta Metall. 30, 947 (1982). 